\title{
Geosciencees
}

http://dx.doi.org/10.1590/0370-44672018720053

luri Brandi ${ }^{1,6}$

Cristiane Silva Sebastião ${ }^{2,7}$

Mauri Lopes Ferreira ${ }^{3,8}$

Hernani Mota de Lima ${ }^{4,9}$

http://orcid.org/0000-0002-5595-4149

Maria Filipa P. Gama ${ }^{5,10}$

http://orcid.org/0000-0002-8084-8954

'VALE S.A. - Espeleologia

Nova Lima - Minas Gerais - Brasil

${ }^{2}$ Tetra Tech Coffey

Belo Horizonte - Minas Gerais - Brasil

${ }^{3}$ MLF Geomecânica

Belo Horizonte - Minas Gerais - Brasil

${ }^{4}$ Universidade Federal de Ouro Preto - UFOP, Escola de Minas, Departamento de Engenharia de Minas,

Ouro Preto - Minas Gerais - Brasil.

${ }^{5}$ Universidade Federal do Rio de Janeiro - UFRJ,

Departamento de Geologia,

Rio de Janeiro - Rio de Janeiro - Brasil.

E-mails: ${ }^{6}$ iuri.brandi@vale.com,

7 cristiane.sebastiao@coffey.com

${ }^{8}$ mauriferreira@uol.com.br, ${ }^{9}$ hernani.lima@ufop.br

${ }^{10}$ gama.filipa@gmail.com

\section{Physical stability of iron ore caves: geomechanical studies of a shallow underground cave in SE Brazil}

\begin{abstract}
Caves hosted in iron formations are attracting considerable interest due to their scientific and environmental value. Some of these caves are located in or near iron ore mine sites, which represent an important source of income to Brazil. However, the Brazilian legislation requires speleological studies that currently have an impact upon ore reserves and environmental licensing processes.

The aim of this study was to apply conventional geotechnical empirical approaches to a cave located within the grounds of an iron ore mine in the Iron Quadrangle and validate it with numerical modelling, to ensure the method's applicability to natural caves under mining activity influence.

These studies comprised the mapping of structural, geotechnical and geomechanical features of rocks hosting and surrounding the cave and to propose geotechnical domains. Field data collection covered the geotechnical parameters necessary to calculate the characteristic Mining Rock Mass Rating (MRMR) for each geotechnical domain, and to evaluate the stability conditions using the stability index or hydraulic radius of the cave. These geotechnical parameters were then used to calculate the physical parameters used in two-dimensional numerical simulations to verify the good stability conditions of the cave, corroborating the adequacy of Laubscher's diagram.

The results of this study, although comprising only one cave, suggest that Laubscher's diagram is applicable for assessing the geotechnical behavior of iron ore caves.
\end{abstract}

Keywords: natural caves; canga; laterite crust; geotechnics; conservation.

\section{Introduction}

Natural caves hosted in iron-rich lithologies (iron ore caves - IOCs) have been identified in several iron-rich formations in the world (Grimes \& Spate, 2008). For some reasons still not fully understood, they appear to be more common in Brazil than in other iron-producing provinces in the world (Parker et al., 2013a). They are not as scenic and rich in speleothems as carbonate caves, but some of them have attributes that deserve to be studied and preserved. The troglobitic fauna is little known, with new species currently being discovered and described (e.g. Iniesta \& Ferreira, 2013; Pellegrini \& Ferreira, 
2017). Some of these caves are palaeoburrows of giant sloths or armadillos, and some contain vestiges of primitive human usage or occupation. On the other hand, as they are hosted in or near highgrade iron ore mines that are important sources of wealth for the country, criteria have been proposed in order to determine which caves may be suppressed during the mining operations and which ones should to be preserved (e.g. Donato et al., 2014; Auler et al., 2017). Brazilian environmental laws are quite strict, although they leave room for compensation for destruction of low, medium and highly relevant caves. The maximum relevance caves must be preserved at all costs, though less relevant ones may be suppressed, subject to permitting processes from the local authorities (BRASIL, 2008).

There are still discussions concerning the speleogenesis processes of the IOCs. Many authors consider their origin to be a result of differential erosion in the interface between the hard cap "canga" and friable material underneath (Grimes \& Spate, 2008), while others believe the origin is hypogenic, originating from the decrease of volume created by the same processes that dissolved the siliceous materials and concentrated the iron oxides that formed the high-grade ore (Auler et al., 2014). Iron-reducing bacteria are also being studied as possibly having played a

\section{Location}

The MP-07 cave is located in the Itabirito (SE Brazil), in a very important mining district of Brazil, the Iron

Quadrangle. It is in the grounds of an iron ore extraction site operated by the Brazilian mining company VALE, be- role in the cave formation (e.g. Parker et al. 2013a, 2013b and 2017).

The understanding of the geomechanical behavior of the rock mass where these natural caves have been developed is essential for iron mining, since its knowledge and characterization are key determinants for defining the iron project forecast with regards to the need for maintenance of the physical integrity of some of the caves. Geomechanical studies provide sources for understanding the relationship between open-pit mining and physical impacts generated in natural caves and allow the design of physical stability monitoring projects for caves during mining operations. Thereby, the key drivers for defining operational procedures can be outlined to allow the coexistence between mining activity and conservation of cave integrity.

Geomechanical studies in caves and mining environment have been conducted in many areas of the world (e.g. Klimchouk \& Andrejchuk, 2002; Waltham \& Park, 2002; Geniş \& Çolak, 2015). Barton (1976) considers limestone cave spans in his empirical graph with satisfactory results. Waltham \& Fookes (2005) applied graphical methods to natural caves and have presented the cave concentration trend in the Q-system's stability chart, specifically concerning limestone caves. In addition, Jordá-Bordehore et al. (2016) and Jordá-Bordehore (2017) have applied the
Q-system's support graph to natural caves and came to the conclusion, considering 137 caves, among which the ones that have the largest spans in the world, that a new empirical limit for evaluating the stability of natural caves could be proposed, having done so. However, the published results refer mostly to caves hosted in limestone or other soluble rock types. Pires et al. (2017) have applied Laubscher's diagram to IOCs in Carajás, Brazil, and have obtained promising results. De Paula et al. (2018) have, complementarily, compared the graphical approach from the MRMR and the Q systems to IOCs, having Laubscher's approach shown to be closer to the expectation considering the cave's spans.

Presently, with the need for conservation of the most relevant IOCs, as the mining fronts get closer to their radius of protection, it has become increasingly important to define simple and feasible criteria and parameters to assess their stability. In this study, the aim was to establish a preliminary way of investigating the influence of mining operations in the stability of adjoining natural caves, by using the results from geomechanical studies developed in a natural cave occurring near two iron mines. The study comprised field mapping and numerical stability analyses, considered as a more robust method to assess the applicability of the essayed empirical method.

tween the Pico and Galinheiro open-pit iron mines (Figure 1).

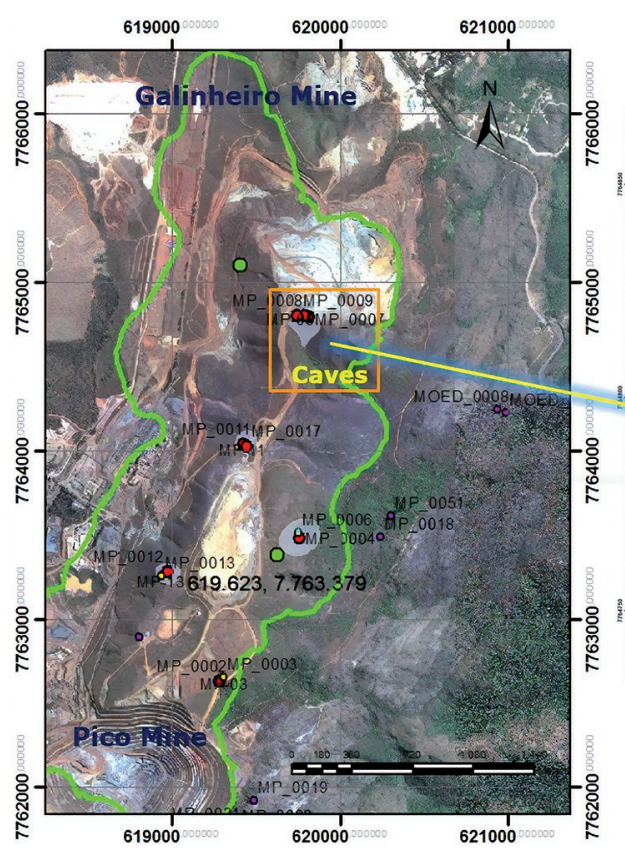

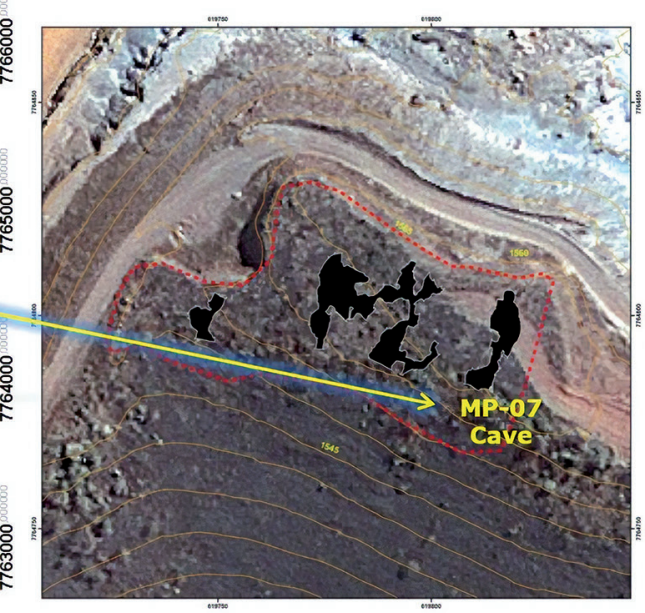

Figure 1

Location of the MP-07 cave. 


\section{Geological characterization}

The MP-07 cave is inserted in the contact zone between the iron formation and the hardened crust, termed 'canga' in Brazil. The predominant rock type observed in the interior of the cave is the iron formation, consisting of leached itabirite (Figure 2a). It can be observed in the whole

Figure 2 MP-07 cave lithologies: (a) iron formation (leached itabirite), (b) detrital canga and (c) - hematitite

\section{Methodology}

\section{Field mapping}

The geomechanical studies developed for the MP-07 cave started with a detailed scale mapping of the structural, geotechnical and geomechanical features of the rocks hosting in the cave and surrounding areas. These studies allowed the identification of the geotechnical variables, necessary to assist the evaluation of the physical stability conditions of the cave.

The internal mapping of the MP-07 cave and surrounding areas comprised the following activities: (1) identification of the lithologies in and

\section{Rock mass classification}

The process contemplated assessing values to the considered parameters for Laubscher's Rock Mass Rating (RMR). Namely, that is: (1) intact rock strength (IRS), (2) spacing of fractured and joints and (3) joint condition and water. The IRS is the unconfined uniaxial compressive strength of the rock between fractures and joints. Spacing is the measurement of all the discontinuities and partings and does not include cemented features, which affect the IRS and as such must be included in that determination. It could be indicated by the Rock Quality Designation (RQD) (Deere \& Miller, 1966), joint spacing (given by a chart) or by the fracture frequency per meter. Finally, the factor for joint condition takes into consideration both large and small-scale expressions northern room and in the basal part of the southern room walls. The detrital canga emerges in the southern room ceiling (Figure 2b). A third rock type, locally called hematitite, can be observed in the central part of the cave (Figure 2c). This rock type consists of high-grade compact ore. It is usually located in fold axes and stands out as projected massive nucleus on the mine slopes. Where the hematitite rock type outcrops, its greater strength prevents further development of the erosive process of the cave, forming passages that are narrower than the others found in other parts of the cave.
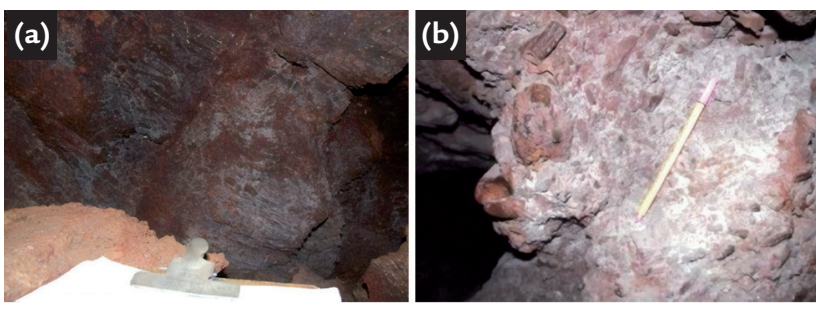

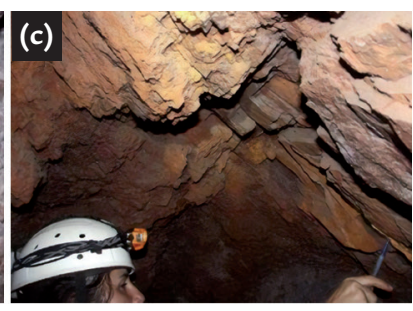

around the cave; (2) estimation of the parameters of weathering and resistance of the involved masses through tactile-visual tests (Barton, 1978); (3) identification and measurement of discontinuity sets and their attitudes, frequency and distribution; (4) characterization of the discontinuities that define anisotropy and influence the geomechanical behavior of the rock masses (spacing, aperture, roughness, filling, walls weathering, frequency and persistence); (5) characterization of the degree of weathering and water presence, and (6) photographic record

of the feature, if there is a distinct difference between the hardness of the host rock and that of the joint wall and joint filling.

Considering the Brazilian legislation regarding natural caves (BRASIL, 2008), there shall be no impacts to caves without previous authorization from environmental agencies. Therefore, the parameters IRS and RQD were estimated via tactilevisual inspection (Barton, 1978) and Priest \& Hudson's equation (1976), respectively, aiming to replicate the methodology in any cave. The other parameters were obtained conventionally, as proposed by the author.

In addition, Laubscher proposes correction factors concerning the mining influence on the excavation and to this corrected index the author of the relevant joints.

In addition, the relationship between the physical conditions of the rock masses in the MP-07 cave and the progress of the mining in the surroundings of the cave were evaluated, especially where it was possible to make observations from the exposures in the cuts of the mine pit slopes.

Data were compiled using a spreadsheet form elaborated to collect the geomechanical parameters necessary for rock mass classification considering Laubscher's proposed approach (1990).

entitles the Mining Rock Mass Rating (MRMR). The author indicates four factors: (1) weathering, (2) joint orientation, (3) mining induced stresses and (4) blasting effects.

The data collected in the field were submitted to the CLASROCK 32 software (Geo\&Soft, 2005), designed to evaluate the geomechanical behavior of the rock mass and to estimate the MRMR values for the identified lithologies. Results obtained from these calculations made it possible to distinguish among geomechanical classes in the cave and surrounding area, favoring the definition of different geotechnical domains.

This parameter was used, together with the stability index (Laubscher, 1990), for self-supporting conditions assessment for an underground cave. 


\section{Empiricalmethod}

There are mainly three conventional empirical methods for excavation stability - Bieniawski's stand-up time chart (1973, 1989), NGI's support graph (Barton et al., 1974; Barton \& Grimstad, 1994) and Laubscher's diagram (1990). The literature review hasn't uncovered any application of Bieniawski's approach

\section{D finite element stress analysis}

The geomechanical parameters were also processed using the RocLab program (Rocscience, 2002) to obtain the physical parameters adopted in the two-dimensional elasto-plastic finite element simulations performed to validate the stability conditions resulted from empirical methods. The software employed to perform these two-dimensional simulations to caves. Barton's support graph, on the other hand, has been tested by a few authors (Waltham \& Fookes, 2005; Renó, 2016; Lacerda et al., 2017; Jordá-Bordehore, 2017), being suggested as conservative. So much that Jordá-Bordehore (2017) has, in fact, proposed a new boundary line for the stability assessment interpre-

was the PHASE2 version 7.0 program (Rocscience, 2008). This program uses a plane strain analysis assuming the two principal in-situ stresses are in the plane of the excavation and the third principal stress is out of plane. It is also assumed that the cross-section of the excavation is constant, and the excavation has infinite out-of-plane length and that there are no shear tations for caves. Finally, Laubscher's diagram has been successfully employed to natural ferriferous caves by Pires et al., (2017) and de Paula et al., (2018) presenting promising results. Therefore, Laubscher's diagram was chosen as the empirical method to have their results compared to numerical modelling simulations.

stresses or strains in the out-of-plane direction.

Therefore, there are limitations to applying this software to natural caves, which are underground voids with varying sections throughout its extension. However, it is effective to simulating stress versus deformation analysis in critical sections, selected for its ceiling shapes and thickness.

\section{Results}

\section{Geomechanical classification}

The geomechanical classes for the lithotypes observed inside the cave were defined by field mapping using the Laub- scher's method (1990). The field data were processed using CLASROCK 32 software. Results obtained from the characteriza- tion and geomechanical classification allowed the definition of three geotechnical domains (Table 1).

\begin{tabular}{|c|c|c|c|c|c|c|}
\hline \multirow[b]{2}{*}{ Parameter } & \multicolumn{2}{|c|}{ Canga cap } & \multicolumn{2}{|c|}{ Compact hematite } & \multicolumn{2}{|c|}{ Leached itabirite } \\
\hline & Characterization & Factor & Characterization & Factor & Characterization & Factor \\
\hline UCS & 100-250 Mpa & 18 & 100-250 Mpa & 18 & 50-100 Mpa & 8 \\
\hline RQD & $25-50 \%$ & 5 & $50-75 \%$ & 5 & $25-50 \%$ & 5 \\
\hline $\begin{array}{l}\text { Spacing of } \\
\text { discontinuities }\end{array}$ & $0.06-0.2 \mathrm{~m}$ & 6 & $0.06-0.2 \mathrm{~m}$ & 10 & $0.06-0.2 \mathrm{~m}$ & 6 \\
\hline $\begin{array}{l}\text { Conditions of } \\
\text { discontinuities }\end{array}$ & $\begin{array}{c}\text { Slightly rough } \\
\text { surface, separa- } \\
\text { tion }<1 \mathrm{~mm} \text {, } \\
\text { highly weathered } \\
\text { wall }\end{array}$ & 21 & $\begin{array}{c}\text { Slightly rough } \\
\text { surface, separa- } \\
\text { tion }<1 \mathrm{~mm} \text {, } \\
\text { highly weathered } \\
\text { wall }\end{array}$ & 21 & $\begin{array}{c}\text { Slightly rough } \\
\text { surface, separa- } \\
\text { tion }<1 \mathrm{~mm} \text {, } \\
\text { highly weathered } \\
\text { wall }\end{array}$ & 21 \\
\hline $\begin{array}{l}\text { Laubscher's } \\
\text { RMR }\end{array}$ & - & 50 & - & 54 & - & 40 \\
\hline Weathering & Fresh & $100 \%$ & Fresh & $100 \%$ & Fresh & $100 \%$ \\
\hline $\begin{array}{l}\text { Joint } \\
\text { orientation }\end{array}$ & $\begin{array}{l}5 \text { joints defining } \\
\text { the block with } \\
2 \text { faces inclined } \\
\text { away from vertical }\end{array}$ & $85 \%$ & $\begin{array}{c}5 \text { joints defining } \\
\text { the block with } \\
1 \text { face inclined } \\
\text { away from } \\
\text { vertical }\end{array}$ & $90 \%$ & $\begin{array}{l}5 \text { joints defining } \\
\text { the block with } 1 \\
\text { face inclined away } \\
\text { from vertical }\end{array}$ & $90 \%$ \\
\hline $\begin{array}{l}\text { Mining induced } \\
\text { stresses }\end{array}$ & $\begin{array}{c}\text { Average rating } \\
30-40 \text { with } \\
\text { plunge degree } \\
>50\end{array}$ & $90 \%$ & $\begin{array}{l}\text { Average rating } \\
30-40 \text { with } \\
\text { plunge degree } \\
>50\end{array}$ & $90 \%$ & $\begin{array}{l}\text { Average rating } \\
30-40 \text { with } \\
\text { plunge degree } \\
>50\end{array}$ & $90 \%$ \\
\hline Blasting effects & Boring technique & $100 \%$ & Boring technique & $100 \%$ & Boring technique & $100 \%$ \\
\hline MRMR & - & 38 & - & 43 & - & 32 \\
\hline
\end{tabular}

Table 1 Geomechanical classification of the rock types observed in the MP-07 cave showing the higher values of the compact hematite.
The first proposed domain was the canga rock type, which forms a very rigid crust. The main characteristics of the canga were its high values of mechani- cal strength, with estimated values for uniaxial compressive strength of about $120 \mathrm{MPa}$. Concerning the fracturing system, the canga has a massive appear- ance, with fracture spacing ranging from centimeters to decimeters. An average spacing from $0.06 \mathrm{~m}$ to $0.2 \mathrm{~m}$ was considered. The cave is located very close to 
the surface, where a very strong canga crust prevails, providing good conditions of self-support to the ceiling.

The second proposed domain was the prevailing compact hematite (hematitite). The main feature was its higher values of mechanical strength, with estimated value reaching over $200 \mathrm{MPa}$. As the studied cave presents weathering features, a value of $160 \mathrm{MPa}$ was adopted for the purpose of its geomechanical characterization and classification.

This domain presented a less accentuated fracture pattern, massive

\section{Stability conditions evaluation}

The MRMR values were used to check the stability of the current cave span through correlation between MRMR and span size, given by the hydraulic radius or stability index, which consists of the span area divided by its perimeter. The ceiling of the MP-07 cave consists predominantly of canga or compact hematite, with MRMR aspect, and fracture spacing typically higher than $0.20 \mathrm{~m}$. An average spacing between $0.015 \mathrm{~m}$ and $0.25 \mathrm{~m}$ was considered. Due to its high mechanical strength, the cave pillars and, in some instances, its ceilings were developed in this rock type. It was observed that this type of rock has a limited presence in the studied cave.

The third proposed domain was that of compact, leached, hardened itabirite, a laminated, metamorphosed oxide-facies iron formation. The key feature of this domain was its mechani-

values ranging from 38 to 43 . To be conservative in the evaluation, considering the Precautionary Principle, a value of 38 was assumed. For this MRMR value, it can be estimated from the abacus in Figure 5 that the cave's stability conditions are suitable for hydraulic ranges below $8.0 \mathrm{~m}$, and that a hydraulic radius from $8.0 \mathrm{~m}$ and $17.0 \mathrm{~m}$ cal strength values lower than those of the two other rock types, with estimated values averaging $80 \mathrm{MPa}$. In relation to the fractures, this rock type presented a highly accentuated fracture pattern, banded aspect, and a fracture spacing typically lower than $0.010 \mathrm{~m}$. An average spacing of $0.006 \mathrm{~m}$ to $0.01 \mathrm{~m}$ was adopted. Due to its high degree of fracturing and consequent deterioration of the strength parameters, it is very susceptible to erosive processes, indicating the cave might have developed through alteration processes in this rock type.

is transitional between stability and roof collapse (caving).

As Figure 3 indicates, the MP-07 cave dimensions are approximately 24.0 length and $8.0 \mathrm{~m}$ average width. Based on these values, the conservative hydraulic radius presented for the present ceiling exposure will be as follows:

$$
\mathrm{HR}=\text { area } / \text { perimeter }=24 \times 8 /(24 \times 2+8 \times 2)=3.0 \mathrm{~m}
$$

The found value of $3.0 \mathrm{~m}$ for MP07 hydraulic radius is much lower than the limit of $8.0 \mathrm{~m}$ for self-supporting conditions, therefore, the cave was in

$$
\mathrm{HR}=\text { area } / \text { perimeter }=11 \times 6 /(2 \times 11+2 \times 6)=1.94 \mathrm{~m}
$$

For this value, it is obtained from the abacus that the stability condi-

Figure 3

Dimensions ( $m$ ) and Hydraulic

Radius Abacus - MP-07 cave

(abacus modified from Laubscher, 1990)

\section{Tensile stress and deformation analysis}

The tensile stress and deformation analysis to verify the stability conditions of MP-07 cave was carried out using a $2 \mathrm{D}$ finite element stress analysis program, PHASE 2 version 7.0 (Rocscience, 2008), based on strength parameters of geomechanical classifi- a safe situation with regards to overall stability conditions.

It can also be observed from Figure 3 that the maximum ceiling exposure in tions are very good in this span, as the maximum hydraulic radius found

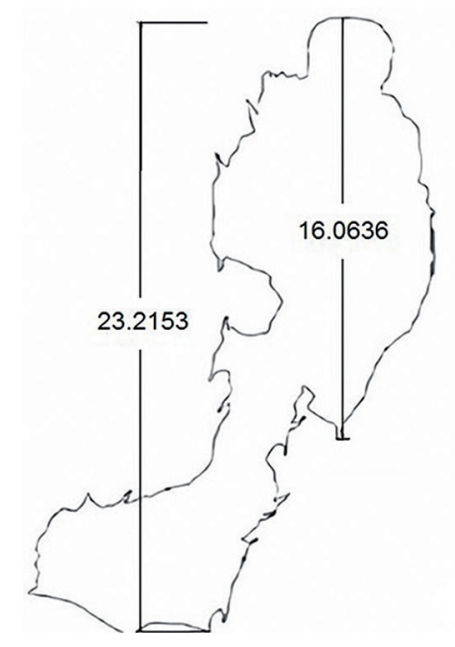

cations and also geotechnical values obtained through RocLab (Rocscience, 2002), a computer software that performs rock mass strength analysis using the generalized Hoek-Brown failure criterion (Hoek et al., 2002). The parameters input into Roclab were consid- the largest chamber of the cave is limited to $11.0 \mathrm{~m}$ long and approximately $6.0 \mathrm{~m}$ wide, providing the following maximum hydraulic radius: is less than $50 \%$ of the self-supporting threshold.

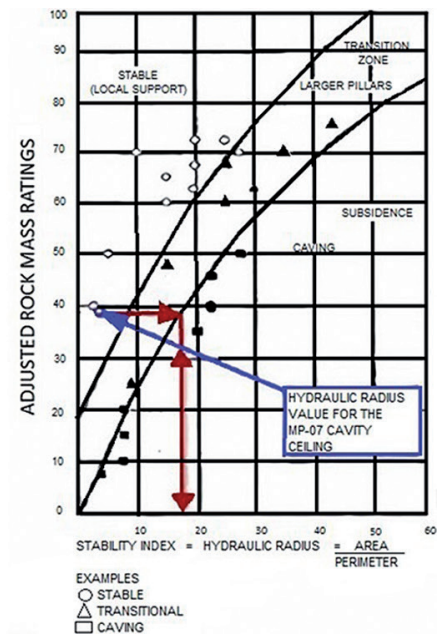

ered given the tactile-visual assessment (Barton, 1978) and the characteristic properties of each lithotype, considering the software inner property tables. Table 2 indicates the Roclab parameters for the three geomechanical domains proposed for MP-07. 


\begin{tabular}{c|c|c|c} 
& Compact hematite & Canga cap & Leached itabirite \\
\hline Hoek-Brown Classification & & & \\
\hline intact uniaxial comp. Strength-sigc (MPa) & 160 & 120 & 80 \\
\hline GSI & 63 & 58 & 53 \\
\hline mi & 19 & 19 & 16 \\
\hline Disturbance Factor(D) & 0 & 0 & 0 \\
\hline Intact modulus-Ei (MPa) & 80000 & 60000 & 20000 \\
\hline Modulus ratio (MR) & 500 & 500 & 250 \\
\hline Hoek-Brown criterion & & & \\
\hline mb (reduced material constant) & 5.068 & 4.239 & 2.986 \\
\hline s (rock mass constant) & 0.0164 & 0.0094 & 0.0054 \\
\hline a (rock mass constant) & 0.502 & 0.503 & 0.505 \\
\hline Mohr-Coulomb fit & & & \\
\hline cohesion & 2.053 & 1.229 & 0.746 \\
\hline friction angle & 65.41 & 64.04 & 60.24 \\
\hline Rock Mass Parameters & & & \\
\hline tensile strength & -0.517 & -0.266 & -0.145 \\
\hline uniaxial compressive strength & 20.292 & 11.460 & 5.735 \\
\hline global strength & 49.833 & 33.641 & 18.612 \\
\hline deformation modulus & 47020.99 & 28480.22 & 7321.38 \\
\hline
\end{tabular}

Figures 4 to 6 show the results of tensile stress $\mathrm{x}$ deformation analysis for the cave in question. The selected section was chosen where the most demanding conditions were expected.

Figure 4 shows the redistribution of tensile stress before and after the the cave opening. A stress relief system can be observed on the ceiling and floor and moderate stress concentration on the sides. These data confirm the expectation of predominance of tensile stresses acting on the rock mass neighboring the cave.
Figure 5 shows the deformations model for the area surrounding the cave. The ceiling deformation is small, ranging from $0.003 \mathrm{~m}$ to $0.006 \mathrm{~m}$. The values calculated for the cave floor, on the other hand, were high, showing a trend for floor uplift, which would be unlikely to happen in practice. A possible explanation for this is the contact of compact hematite and canga (ceiling) and leached itabirite (lower walls and floor). The strength factor values calculated and displayed in Figure 6 confirm the previ-
Table 2

Geotechnical ratings for the three geotechnical domains in cave MP-07.

ous statement. It can be noticed that, for the floor, the calculated values were around 4.4, whilst, for the cave ceiling, these values fluctuate around 6.0. The strength factor is given by the ratio of the rock strength and the induced stress at every mesh point. This is the reason why the factor became greater in the ceiling, reflecting its greater rock strength with the proximity to the compact hematite, indicating that the strength values obtained are consistent with the geotechnical domains proposed.
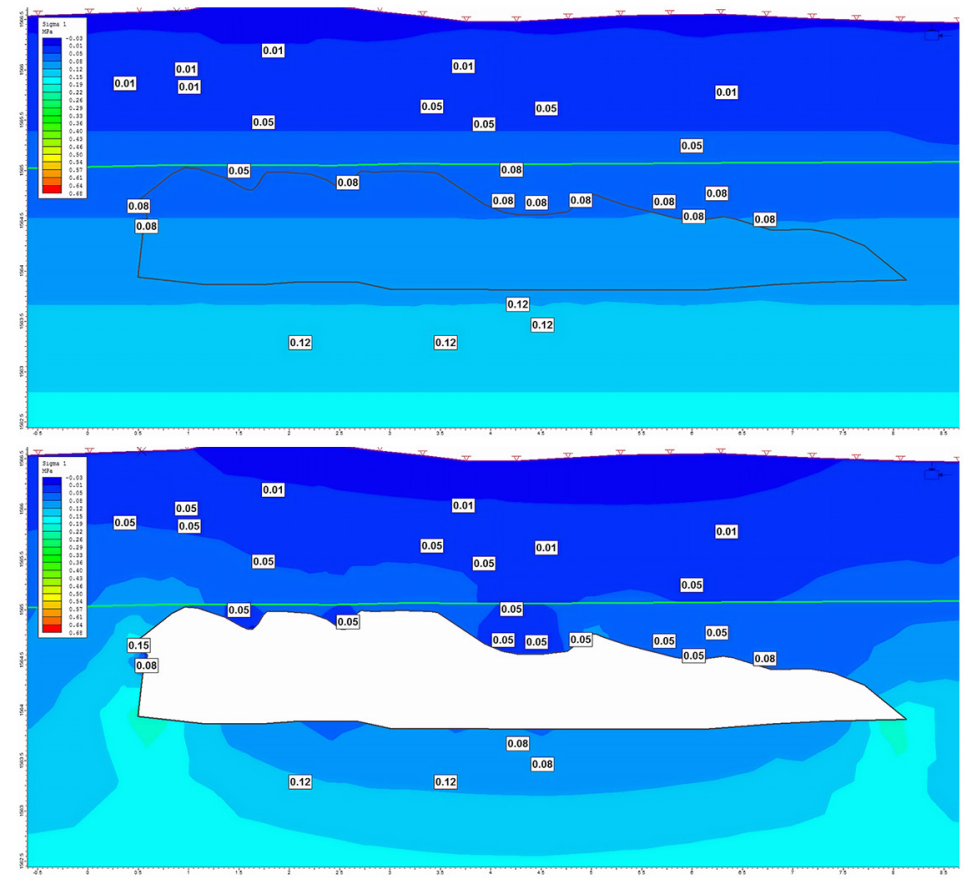

Figure 4

Distribution of stress before (top) and after (bottom) the MP-07 cave opening. 
Figure 5 MP-07 cave deformation.

Figure 6 Strength Factor in MP-07 cave.

\section{Discussion}

The three geotechnical domains defined by the detailed mapping of the MP-07 correlated very well with the numerical simulations, suggesting that the same classification methodology can be extended to other caves mapping in similar geological environments.

As regards the stress state of a rock mass, it is well known that it is a function of the weight of the overlying rock types and the tectonic stresses acting on the mass, being the deformations, thereof, result of the interaction of the state of stress with the geomechanical characteristics of the rock types which constitute the rock mass. An underground excavation or the development of a cave induces a rearrangement in the distribution of stress and, eventually, a stress accumulation accord-

\section{Concluding remarks}

When a reasonable amount of data for several IOCs is available, a modified abacus should be proposed and its applicability tested for a number of caves, using for validation, similarity to the work of Waltham \& Fookes (2005) and the adapted graph proposed by JordáBordehore (2017), which considered a large number of natural caves inserted in
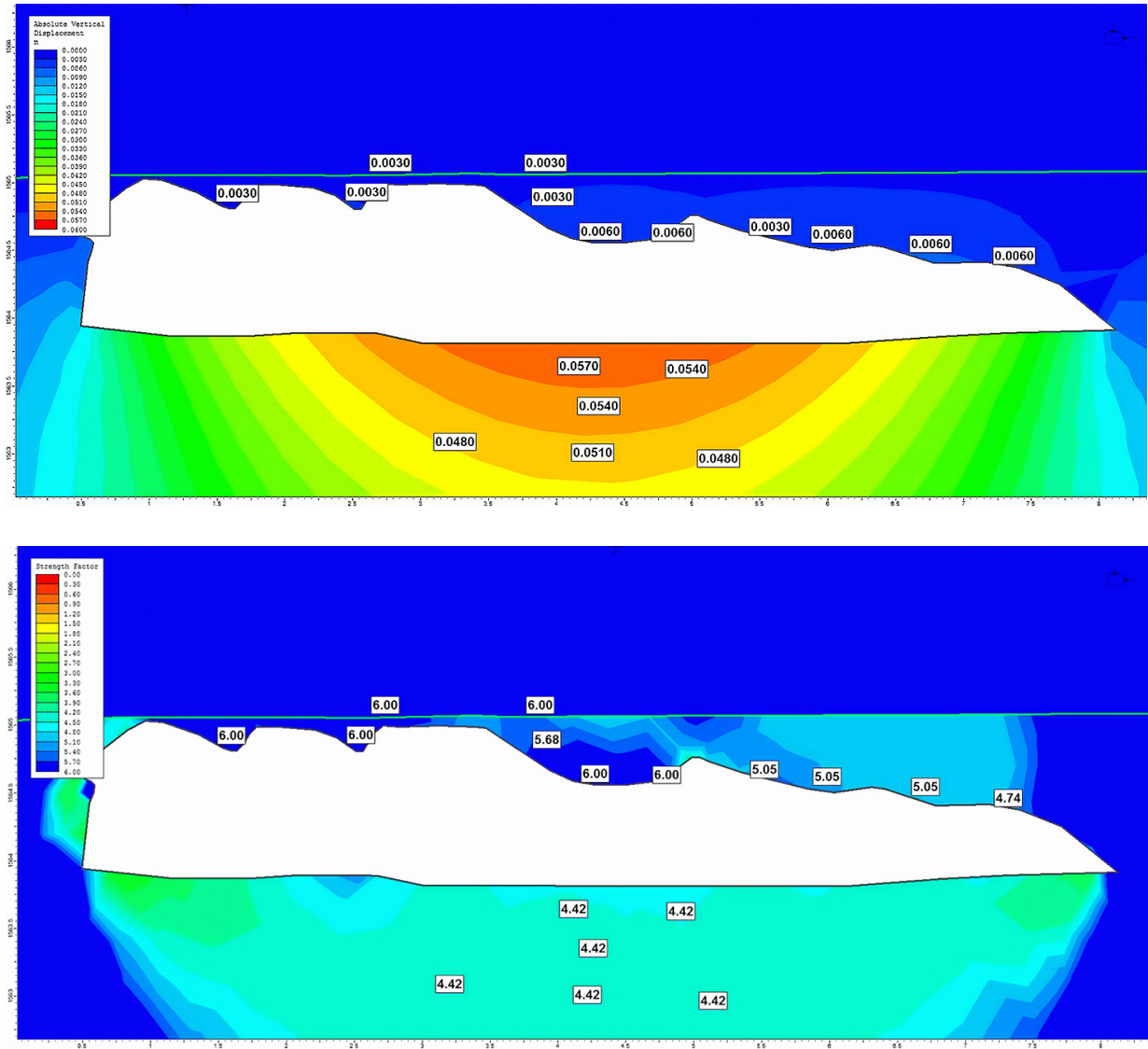

ing to the geometry of the cave that can surpass the rock resistance and provoke instability. Regardless, a tensile stress and deformation analysis demands much more effort than employing empirical methods.

The results suggest the simulations carried out using the hydraulic radius theory for estimating the geomechanical stability of underground excavations are applicable to estimate the stability of iron ore caves, given the two-dimensional numerical simulations for MP-07 cave corroborated the outcome.

Both Laubscher's diagram and the numerical modelling presented high degrees of safety for the studied span, given by the rate of actual hydraulic radius compared to the threshold value from the diagram and by the strength factors

limestone and other lithologies.

In further studies, other simulations could be done by varying the strength parameters and physical indexes, as well as to simulate other geotechnical situations for other caves sections. It is suggested that an adequate instrumentation and monitoring program for the caves in iron ore mines would allow for the quantification numerically obtained, respectively.

In general, the results of the numerical simulations for the MP-07 cave confirmed the expected good stability conditions obtained by applying the hydraulic radius theory, therefore suggesting that simple empirical methods, based upon careful field mapping of the involved rock mass parameters, can be employed to assess the geotechnical stability of caves with much less effort.

Thus, it is understood that although the method has been applied to one cave only in this study, and the given results indicate the sequence of traditional mapping and empirical approaches can be easily replicated to other caves, which will bring more credibility and maturity with time and usage.

and analysis of cause and effect phenomena, in order to subsidize the definition of operational and control parameters to determine the safe distances for mining operations in regions with natural caves, and/or to refine the operational procedures related to blasting operations, aiming to guarantee their physical integrity. 


\section{Acknowledgements}

This study was supported by VALE. We are indebted to the VALE and TETRA
TECH BRASIL teams, who provided the data for this study. We would like to thank the reviewers for their detailed comments and suggestions for the manuscript.

\section{References}

AULER, A. S. et al. Hypogene cave patterns in iron ore caves: Convergence of forms or processes? In: HYPOGENE CAVE MORPHOLOGIES, 7., 2014, San Salvador Island, Bahamas. Proceedings.... Leesburg: Karst Waters Institute, 2014. p. 15 - 19. (Special Publication 18).

et al. A review and statistical assessment of the criteria for determining cave significance. In: GEOLOGICAL SOCIETY . Geological Society Special Publication. Londres: Geological Society, 2018. p. 443-459. v. 466

BARTON, N. R. International society for rock mechanics commission on standardization of laboratory and field tests. International Journal Of Rock Mechanics and Mining Sciences \& Geomechanics Abstracts, [s.1.], v. 15, n. 6, p.319-368, dez. 1978.

. Unsupported underground openings. In: ROCK MECHANICS DISCUSSION MEETING, 1976. Stockholm. Proceedings... [S.l.], [s.n], 1976. p. 61-94

, GRIMSTAD, E. The Q-system following twenty years of application in NMT support selection. In: GEOMECHANICAL COLLOQUY, 43. 1994. Salzburg. Proceedings... [S.1.], [s.n], 1994. v. 6, n. 94, p. 428-436.

, LIEN R., LUNDE J. Engineering classification of rock masses for the design of tunnel support. Rock Mechanics, [s.1.], v. 6, n. 4, p.189-236, dez. 1974.

BIENIAWSKI, Z, T. Engineering classification of jointed rock masses. The Civil Engineer in South Africa. [s.1.], v. 15, n. 12, p.335-344, 1973.

. Engineering rock mass classification: a complete manual for engineers and geologists in mining, civil, and petroleum engineering. John Wiley \& Sons, 1989. $272 \mathrm{p}$.

BRASIL. Decreto n 6.640 , de 7 de novembro de 2008. Diário Oficial [da] República Federativa do Brasil, Poder Executivo, Brasília, DF, 10 nov. 2008, Seção 1, p. 8-9.

DE PAULA, A. Q. et al. Natural caves empirical stability assessments: application of Laubscher's diagram and Barton's support graph. In: SIMPÓSIO BRASILEIRO DE MECÂNICA DAS ROCHAS, 8. 2018. Salvador. Anais... Salvador: [s.n], 2018.

DEERE, D. U., MILLER, R. P. Engineering classification and index properties for intact rock. Urbana: University of Illinois: 1966. 300p. (Technical report $n^{\circ}$ AFWL-TR-65-116).

DONATO, C. R., RIBEIRO, A. S., SOUTO, L. S. A conservation status index, as an auxiliary tool for the management of cave environments. International Journal of Speleology, [S.1.], v. 43, n.3, p. 815-822, 2014.

GENIŞ, M., ÇOLAK, B. Stability assessment of the Gökgöl karstic cave (Zonguldak, Turkey) by analytical and numerical methods. Rock Mechanics and Rock Engineering, v. 48, n. 6, p. 2383-2403, 2015.

GEO\&SOFT. ClasRock 32: classification of the rock masses. 2006. Disponivel em: <http://www.geoandsoft.com/english/barton_bieniawski.htm>. Acesso em: 12 nov. 2018.

GRIMES, K., SPATE, A. Andysez n ${ }^{\circ}$ 53: laterite karst. Australasian Cave and Karst Management Association (ACKMA) Journal, Melbourne, n. 73, p. 49-52, 2008.

HOEK, E., CARRANZA-TORRES, C., CORKUM, B. Hoek-Brown failure criterion: 2002. edition. In: NORTH AMERICAN ROCK MECHANICS SYMPOSIUM, 1. 2002. Toronto. Proceedings... Toronto: [s.n.], 2002. p. 267-273.

INIESTA, L. F. M., FERREIRA, R. L. The first troglobitic Pseudonannolene from Brazilian iron ore caves (Spirostreptida: Pseudonannolenidae). Zootaxa, Auckland, v. 3669, n. 1, p. 85-95, 2013.

JORDÁ-BORDEHORE, L. Stability assessment of natural caves using empirical approaches and rock mass classifications. Rock Mechanics and Rock Engineering, Vienna, v. 50, n. 8, p. 2143-2154, 2017.

JORDÁ-BORDEHORE, L. et al. Stability assessment of shallow limestone caves through an empirical approach: application of the stability graph method to the Castañar Cave study site (Spain). Bulletin of Engineering Geology and the 
Environment, Berlin, v. 75, n. 4, p. 1469-1483, 2016.

KLIMCHOUK, A., ANDREJCHUK, V. Karst breakdown mechanisms from observations in the gypsum caves of the Western Ukraine: implications for subsidence hazard assessment. International Journal of Speleology, Postojna, v. 31, n. 1, p. 55-88, 2002.

LACERDA, S. G. et al. Caracterização geomecânica do maciço rochoso da Gruta dos Viajantes, Parque Estadual do Ibitipoca, sudeste de Minas Gerais. In: CONGRESSO BRASILEIRO DE ESPELEOLOGIA, 34. 2017. Ouro Preto. Anais... Ouro Preto: Sociedade Brasileira de Espeleologia, 2017. p. 261-275.

LAUBSCHER, D. A. Geomechanics classification system for the rating of rock mass in mine design. Journal of the Southern African Institute of Mining and Metallurgy, Johannesburg, v. 90, n. 10, p. 257-273, 1990.

RENÓ, T. S. N. Proposta de zoneamento geotécnico de cavidades naturais em formações ferríferas. Ouro Preto: Universidade Federal de Ouro Preto, Escola de Minas, 2016. 203 p. (Mestrado em Engenharia Mineral).

PARKER, C. W. et al. Fe (III) reducing microorganisms from iron ore caves demonstrate fermentative $\mathrm{Fe}$ (III) reduction and promote cave formation. Geomicrobiology Journal, [S.1], v. 35, n. 4, p. 311-322, 2017.

. et al. Microbial iron cycling and biospeleogenesis: cave development in the Carajás Formation. In: INTERNATIONAL CONGRESS OF SPELEOLOGY, 16. 2013. [S.1]. Proceedings... Prague: [s.n], p. 442-446, 2013.

. et al. Microbial reducibility of Fe (III) phases associated with the genesis of iron ore caves in the Iron Quadrangle, Minas Gerais, Brazil. Minerals, [S.l], v. 3, n. 4, p. 395-411, 2013.

PELLEGRINI, T. G., FERREIRA, R. L. Two new troglobitic Coarazuphium Gnaspini, Godoy \& Vanin 1998 species of ground beetles from iron ore Brazilian caves (Coleoptera: Carabidae: Zuphiini). Zootaxa, [S.1], v.4306, n. 4, p. 551-566, 2017.

PIRES, M. A. et al. Ábaco de autoportabilidade de vãos de Laubscher: aplicação da ferramenta em cavidades naturais subterrâneas em rochas ferríferas. In: SIMPÓSIO MINEIRO DO CARSTE, 3. 2017. Anais... Belo Horizonte: [s.n], 2017.

PRIEST, S. D., HUDSON, J. A. Discontinuity spacings in rock. International Journal of Rock Mechanics and Mining Sciences \& Geomechanics Abstracts, [S.1] v. 13, n. 5, p. 135-148, 1976.

ROCSCIENCE. Phase 2 - Finite element analysis for excavations and slopes. Toronto, 2008. Disponível em: <https://www.rocscience.com>. Acesso em: 12 nov. 2018.

ROCSCIENCE. Roclab - rock mass strength analysis using the generalized Hoek-Brown failure criterion. Toronto, 2002. Disponível em: <https://www.rocscience. com>. Acesso em: 12 nov. 2018.

WALTHAM, A. C., PARK, H. D. Roads over lava tubes in Cheju Island, South Korea. Engineering Geology, [S.1], v. 66, p. 35-64, 2002.

WALTHAM, T., FOOKES, P. G. Engineering classification of karst ground conditions. Quarterly Journal of Engineering Geology and Hydrogeology, [S.1], v. 36, n. 2, p. 101-118, 2005.

Received: 16 April 2018 - Accepted: 6 November 2018. 